\title{
Nationalist Internationalism in the Modern Age
}

\author{
David Motadel
}

On the morning of 24 June 2016, the day after the UK EU referendum, right-wing nationalists across Europe (and beyond) were united in their jubilation, hailing the result as a victory of the supremacy of the nation over a crumbling liberal order. From the Front National's party headquarters outside Paris, a triumphant Marine Le Pen announced the beginning of a 'patriotic' international 'movement' that 'can't be stopped'. In the Netherlands, far-right leader Geert Wilders celebrated the referendum's 'huge consequences', declaring that the people needed 'a national identity', 'to rally around a flag'. In Germany, Frauke Petry proclaimed that the time was ripe to 'mobilise' all nationalist forces 'across all borders' to forge a 'Europe of fatherlands'. Her deputy, Beatrix von Storch, said she had 'wept for joy'. The transnational chorus of nationalists also included Hungary's Victor Orban, Italy's Matteo Salvini, Denmark's Kristian Thulesen Dahl, Austria's Heinz-Christian Strache and many others. From a golf course in Scotland, presidential candidate Donald Trump hailed the vote as a 'great thing', seeing a 'big parallel' to the mood in the United States where people also wanted to 'take their borders back'. Demonstrating a remarkable degree of solidarity, they felt energised, bridging parochial nationalism and cosmopolitan internationalism. The United Kingdom's 'Leave' campaign needs to be understood as a part of a much longer history of right-wing international networks and shared aspirations.

The phenomenon is hardly new. Transnational bonds between right-wing nationalist movements are as old as these movements themselves. United in a global struggle against their liberal and socialist enemies, nationalists throughout the nineteenth and twentieth centuries operated not only in national but also in transnational and international spaces. Historically, as we have been reminded by scholars like Patricia Clavin, Jessica Reinisch and Glenda Sluga, nationalism and internationalism have always been closely intertwined. Crossing national boundaries, nationalists have often also been remarkably cosmopolitan. Although scholars have shown great interest in the study of cosmopolitanism, both as an idea and as a practice performed by humans across the world, with diverse forms contingent on historical circumstances, they have predominantly assumed it to be the opposite of nationalism. Yet particularist nationalism and universalist cosmopolitanism are not necessarily incompatible. In theoretical terms cosmopolitanism is only possible (thinkable), dialectically, if there is a conception of the own (and multiple others), individual or (and) collective. Cosmopolitanism may well accommodate national differences. As a consequence a cosmopolitanism which implicitly recognises national differences can also be embraced by nationalists. Whether they have done so in practice has depended on historical circumstances. Usually the cosmopolitanism of right-wing nationalists, which we may call 'reactionary cosmopolitanism', has served as a means to pursue their concrete political agendas.

To understand modern right-wing nationalist internationalism in its various forms - including as articulated as part of the campaign for the United Kingdom to leave the European Union - we need to understand the close historical connections between nationalism and internationalism. Indeed they are siblings, born in the nineteenth century. A response to the reactionary anti-revolutionary politics of the Concert of Europe, which itself was an internationalist alliance, both socialists and liberal nationalists formed internationals to rally their respective forces against the conservative restoration. Many nineteenth-century nationalists were cosmopolitans,

() Cambridge University Press 2019. 
considering the national order to be universal, and organised their struggle across borders. One of the most famous was the revolutionary Giuseppe Mazzini, who fought not only for Italian national unification but also for other national causes across Europe. Promoting an international association of nations, his People's International League advocated 'the Rights of Nationality' and a 'cordial understanding between the Peoples of all countries'. Mazzini's comrade Giuseppe Garibaldi not only fought for the Italian Risorgimento but also supported the Geneva-based International League of Peace and Liberty, with its internationalist journal États-Unis d'Europe. Even as nationalists radicalised from the late nineteenth century, becoming increasingly anti-liberal, chauvinistic and authoritarian in the process, their internationalism often remained strong.

The global wave of socialist upheavals following the October Revolution gave momentum to a powerful reactionary counter movement. In the anti-communist moment of 1917-21, nationalists, ranging from moderate conservatives to far-right militants, united against the perceived communist threat. Many of them fought within their countries' borders but most perceived their fight as part of an international struggle. One of the advocates of this right-wing international, Nicholas Murray Butler, president of Columbia University, differentiated in a 1917 tract between 'colloidal' and 'crystalline' internationalism. While 'colloidal internationalism' was, for him, the 'hopelessly impractical', 'unsound' and 'unstable' internationalism of liberals and the left, seeking 'a world-wide community without national ties or national ambitions', 'crystalline internationalism' was a noble internationalism based on 'nationalistic and patriotic sentiments and aims', being 'elements in a larger human undertaking of which each nation should be an independent and integral part'. (Butler, A World in Ferment: Interpretations of the War for a New World, 1917, 7-8) Statements such as these show how contemporaries themselves made the distinction between traditional liberal (and socialist) and nationalist internationalism. To be sure, the interwar right-wing international was not only anti-Bolshevik, it was also ardently antiliberal. One of its early arenas was the Geneva International, the Entente Internationale contre la IIIe Internationale, founded in 1924 by the Swiss right-wing intellectual Theodore Aubert and the Russian Red Cross functionary Georges Lodygensky. Committed to 'defending the principles of order, family, property and nationality' in 'all countries', it organised international gatherings, coordinated the activities of its members and produced propaganda periodicals, books and films. It brought together right-wing nationalist, anti-communist movements from no fewer than eighteen countries, with members from Europe, America, Australia, New Zealand, North Africa and Latin America. Its cosmopolitan networks included Francisco Franco in Spain, Philippe Pétain in France and Franz von Papen in Germany. The leaders of the Geneva International also embraced Mussolini and Hitler and cooperated with the Italian Centro di Studi Internazionali sul Fascismo and the Nazi Anti-Komintern.

The 1920s and 1930s saw the rise to power of authoritarian nationalist and fascist movements across the world: Mussolini in Italy (1922), Salazar in Portugal (1928), Hitler in Germany (1933), Franco in Spain (1936), Vargas in Brazil (1937) and Phibulsonggram in Siam (1938). Creating new transnational spaces to organise their struggle against socialism and liberalism, from the outset the new regimes engaged in international cooperation and acted as patrons of right-wing movements in countries that had not yet been taken over, a phenomenon pointed to by historians like Michael Leeden (when still a serious scholar), Arnd Bauernkämper and Madeleine Herren. 'Fascism is now an international movement, which means not only that the Fascist nations can combine for purposes of loot, but that they are groping, perhaps only halfconsciously as yet, towards a world system', remarked George Orwell in 1937 (Orwell, The Road to Wigan Pier).

The fascist international gathered frequently at conferences. The most notable was the 1934 Conference of Fascist Parties in Montreux, organised by Mussolini's Comitati d'Azione per l'Universalità di Roma, which was to forge a transnational alliance to combat socialism and liberal democracy. All major fascist regimes organised a wide range of international meetings and 
internationalised their own national political congregations. At their 1938 Nuremberg Party Rally the Nazis welcomed fascist youth groups not only from Spain, Italy and Romania but also from Japan, Siam, Bolivia and Iraq. The regimes also established internationalist organisations that were meant to connect fascist movements across the world, including the Fasci Italiani all'Estero or the Nazi Party's Auslandsorganisation. Most importantly, fascist movements actively supported each other politically, financially and militarily. Mussolini funded the British Union of Fascists, which Oswald Mosley had founded after a visit to Rome in 1932, the Heimwehr and Léon Degrelle's Belgian Rexists; he also kept close ties with Corneliu Codreanu's Iron Guard, Ference Szálasi's Arrow Cross and Ante Pavelić's Ustaša. Similarly, Hitler gave financial support to fascist groups abroad. Fascist internationalist collaboration was nowhere more visible than in the Spanish Civil War. As socialists from across the world flocked to Spain to swell the ranks of the International Brigades, fascist and right-wing nationalist militants, albeit fewer in number, fought alongside the nationalists, from Irish fascists to Romanian Iron Guard die-hards; this is not to mention the support Franco received from the regimes in Berlin, Rome and Lisbon.

Besides these cooperations, the new authoritarian regimes also worked within existing international organisations. Although full of contempt for the League of Nations, they remained active members of many other international institutions. The Reichsbank, for example, remained a member of the Bank for International Settlements. Fascist regimes increasingly dominated the International Prison Commission; in 1935, its international congress convened in Berlin, attended by Goebbels. The Nazis worked with the International Olympic Committee, turning the 1936 Summer Olympics into an international celebration of the 'new man'. In 1938 Germany took over the International Criminal Police Commission - Interpol's predecessor - based in Vienna, and two years later Hitler's hangman Reinhard Heydrich became its new president.

This right-wing internationalism peaked during the Second World War. The Anti-Comintern Pact, signed by Tokyo and Berlin in 1936 (and in 1937 by Italy and Spain), was revised in 1941 to include, among others, Finland, Hungary, Bulgaria, Romania, Croatia, El Salvador and, as observer, Turkey. Forging an Axis internationalism, the Tripartite Pact, signed by Germany, Italy and Japan in 1940, was not only a military alliance, it also led to cooperation in research, culture and sports. Berlin even published a glossy bilingual journal, Berlin-Rom-Tokyo, to celebrate this internationalism, featuring articles ranging from the Germans in Hsinking to Japanese art exhibitions in Germany. As the tide of war turned against the Axis and Berlin began promoting the conflict even more vigorously as an international struggle against world Bolshevism, they recruited volunteers from across the continent (and beyond) into their armies. Even anti-colonial leaders joined this international, whether as part of Japan's pan-Asian alliance, centred on the project for the Greater East Asia Co-Prosperity Sphere, or in Berlin's anti-colonial international, which brought together anti-colonial nationalists from the Middle East, South Asia and North Africa. To be sure, many of these international cooperations were the result of significant pragmatism, but there was a global consensus that fascism was indeed an international project.

In the post-Second World War world, the far right, although crippled as a political force, continued to organise itself internationally. Examples range from the extremist World Union of National Socialists launched in 1962, which opened sections across the Americas, Europe and Asia, to the World Anti-Communist League, created in 1966, which brought together the extreme right with more moderate conservatives. Prominent international meetings included a camp organised in 1961 by the British National Party, with delegations from the United States, Austria, France, Germany and Sweden, and the World Nationalist Congress, convened by American neo-fascists in the mid-1970s, with guests from the United Kingdom, Germany, Belgium and other countries, issuing declarations in support of South Africa and Rhodesia, requests for the release of Nazi war criminals and announcements of solidarity with 'all White Nationalists throughout the world'.

Moreover, at the national congresses of right-wing organisations, such as the Order of Flemish Militants, the French and European Nationalist Party (and also the Front National), the Golden 
Dawn and Germany's National Democratic Party, foreign delegations were regular participants. Indeed, the post-war far right never made a secret of its internationalist ambitions. In the early 1960s the British National Party officially declared that it was 'as much concerned with the fate of our people in Melbourne as those in Manchester, or those in Stockholm and those in Sheffield', and that the 'co-operation and comradeship' with allies across borders was to forge a united nationalist 'world movement'. To be sure, such cooperations were not free of frictions and involved clashes between different far-right groups over questions concerning the relations between their countries. Their members did not always support their movements' internationalist politics. But overall, the 'transnational right', to use the words of Martin Durham and Margaret Power, was an integral part of the twentieth-century global political landscape.

The most recent global nationalist resurgence is no different. Le Pen's Front National, Orban's Fidesz, Kaczyński' Law and Justice Party, Erdogan's Justice and Development Party, Salvini's Lega Nord, Strache's Freedom Party of Austria and Modi's Indian People's Party, as diverse as they might be, are united in their anti-liberal nationalism, hatred of ethnic, religious and sexual minorities, weakness for authoritarianism and scorn for multiculturalism and pluralism. All of these movements, even though less militant than many of their fascist and neo-fascist predecessors, try to connect the extremist far right with the conservative centre. Indeed, the boundaries between them and conservative parties are at times fuzzy. In the United States, farright policies were adopted by Trump's Republican Party, now advocating Muslim bans, immigrant internments and ultra nationalism. Theresa May's Conservative Party aligned itself with much of the UK Independence Party's political programme.

Ironically, the cooperation between some of these groups can be observed in the European Parliament, most notably in the Europe of Nations and Freedom parliamentary group. In its official declaration the faction stated its aim as 'the preservation of the identity of the peoples and nations of Europe, in accordance with the specific characteristics of each people' and 'cooperation between nations' rather than 'a supra-state'. And their internationalism continues to crystallise at congresses, symposia and rallies. Salvini, who praised the 'good work' of Mussolini, attended a Trump election rally in Philadelphia in 2016. Le Pen, Wilders, Salvini and their allies frequently stage their solidarity at meetings. Following the British EU referendum and Trump's victory, Le Pen, Wilders, Petry and others gathered in Koblenz, with Le Pen declaring, somewhat prematurely: '2016 was the year the Anglo-Saxon world woke up. 2017, I am sure, the people of continental Europe will wake up.' Soon after, invited by Poland's far-right government, Trump addressed cheering crowds at Warsaw's Krasinski Square, calling for the defence of 'Western civilisation' against enemies, 'whether they come from inside or out, from the South or the East'. A year later, Trump's emissary in Berlin, Richard Grenell, pledged to 'empower' Europe's right. Forming an international front against multiculturalism, all these political leaders have crossed borders to establish borders (sometimes literally). In 2018 Steve Bannon, former Trump whisperer, who cites Julius Evola as his intellectual inspiration, formed 'The Movement', headquartered in Brussels, to forge a European right-wing international; a group of reactionary cosmopolitans, its members have vowed to pave the way for a nationalist resurgence. The Brexiteers of Farage's UK Independence Party have already signed up.

Looking back over two centuries, right-wing nationalist internationalism has had many faces. Its actors have been diverse, ranging from local to national movements and states. Their agendas have changed over time, although the core enemies have remained liberalism, socialism and multiculturalism. Sceptical of supranational organisations, such as the League of Nations, the United Nations and the European Union, as subversive to 'national sovereignty', they have promoted cooperation between autonomous nations. Their internationalism built on the assumption of the existence of supposedly homogenous, essentialised, closed national communities. It has been both a form of activism and a political idea. Enabled by modern communication technology, from the telegraph to the internet, as well as modern means of transport, right-wing nationalists have created their own transnational spaces of sociability and encounter. 
The interplay between nationalist and internationalist agendas has been complex. At times the nationalists' parochial views, or 'territorial instincts', as Charles Maier put it, have made international cooperation difficult. Territorial loyalties have always remained crucial. But strikingly, right-wing cosmopolitanism has never been all-inclusive; it brings people together, across borders, to exclude others both inside and outside their own respective borders. From the outset, the UK's 'Leave' Campaign was very much embedded in this international and part of the as yet unwritten history of the globalisation of right-wing politics. 